\title{
Microbiology Factor Measurement as Indoor Air Quality Parameter in Public Space
}

\author{
Oktofa Setia Pamungkas', Henny Ayu Nirwala ${ }^{2)}$, Dina Mala Pardede ${ }^{3)}$ \\ ${ }^{1,2,3)}$ Occupational Health and Safety Office (BK3) Samarinda \\ email: oktofa.sp@gmail.com
}

\begin{abstract}
Nearly $90 \%$ of people spend their time in both private and public indoor spaces. Bank is one of the public indoor spaces accessible to the community, as well as a place for some workers spending time every day. This study was conducted in 6 banking sectors in Samarinda, East Kalimantan, focusing on the existence of microorganisms such as bacteria and fungi/mold. The purpose was to investigate the number of microorganisms, both bacteria and fungi, contained in indoor areas of several bank offices in Samarinda. The results showed that the number of bacteria and fungi at several sampling points in 6 offices were above the standard of Permenaker RI No. 5 the year of 2018 and Permenkes RI No. 48 the year of 2016, i.e., >700 cfu/m3 for bacteria and $>1000 \mathrm{cfu} / \mathrm{m} 3$ for fungi.
\end{abstract}

Keywords: Microbiology Factor, Indoor Air Quality, Public Spaces.

\section{INTRODUCTION}

Human spends nearly $90 \%$ of their time in private as well as public indoors such as houses, gyms, schools, public transportations, and banks (Cincinelli and Martellini (2017). This condition makes the community easier to expose to several indoor hazards. An indoor environment (bioaerosol) can affect human health and physical conditions (Dacarro, 2005). Indoor air quality is known to determine the quality of public health (Jantunen et al., 2011). Previous researches prove that problems with indoor environmental quality such as thermal, acoustic, visual, and air quality of a building have a direct effect on the comfort, health, and productivity of the occupants (Wulandari, 2013; Abdullah dan Hakim, 2011; Wismana, 2016). Indoor microenvironment has unique characteristics, which are determined by local outdoor air, specific characteristics of buildings, and indoor activities (De Giuli et al., 2012; Pegas et al., 2012; Spring et al., 2011).

Indoor air quality refers to the quality of air in and around buildings, especially those relating to the health and comfort of a building's occupants (EPA, 2019). Research conducted in the last 20 years by the United States Environmental Protection Agency found that indoor air is often more polluted than outside air, and indoor air pollution has been ranked among the five top risks to public health (Gawrońska and Bakera, 2015). Building materials and coatings, carpets, furniture, liquids and cleaning products, cigarettes, air cooling systems, copiers, markers, and other materials are some of the sources of indoor air quality problems (Tamburrano et al., 2017). The source of indoor air quality problems can also come from microorganisms present in the air, including bacteria, fungi, and viruses (Gocgeldi et al., 2011).

Indoor air quality becomes a serious discussion because humans spend most of their time indoors (Zhang and Smith, 2003). One of the indoor spaces is a bank. Bank is one of the legal entities engaged in financial services and one of the most important public indoor spaces (Paparang, 2016). Therefore, the air quality inside the banks must be optimal, both in the term of environmental factors and in the amount of microbial contamination.

Bioedukasi Vol. XVII. No. 2 October 2019

Received 19 August 2019| Received in revised form 16 September 2019| Accepted 30 September 2019| Published online 7 October 2019 
Microbial air qualities are an important consideration when one is designing an indoor workplace to provide a safe and comfortable work environment. The purpose of this research is to investigate the number of microorganisms, bacteria and fungi, in indoor air space in several bank offices in Samarinda, East Kalimantan.

\section{RESEARCH METHOD}

The focus of this study was to collect data of bacteria and fungi in several indoor spaces of bank offices in Samarinda, East Kalimantan. Additional data obtained from the measurement of relevant physical factors include air temperature, humidity, and wind speed. The study was conducted in 6 banking offices. The data measurement was carried out in three rooms of each office, i.e., service room, employee room, and office hall. The method used to trap microbes was agar filter using QuickTake ${ }^{\circledR} 30$ vacuum pump with constant flow at $20 \mathrm{~L} / \mathrm{mins}$ and run for 5 minutes for each room. The incubation and determination were carried out in laboratory.

\section{RESULTS AND DISCUSSION}

The measurement result of microbial counts and physical factors is presented in Table 1:

Table 1. Result of microbial counts and physical factors measurement

\begin{tabular}{|c|c|c|c|c|c|c|}
\hline \multirow[b]{2}{*}{$\begin{array}{c}\text { Sampli } \\
\text { ng } \\
\text { Point }\end{array}$} & \multirow[b]{2}{*}{$\begin{array}{c}\text { Locat } \\
\text { ion }\end{array}$} & \multicolumn{2}{|c|}{ Parameters } & \multicolumn{3}{|c|}{$\begin{array}{c}\text { Environmental } \\
\text { Data }\end{array}$} \\
\hline & & $\begin{array}{c}\text { Bacte } \\
\text { ria } \\
(\mathbf{c f u} / \\
\left.\mathrm{m}^{3}\right)\end{array}$ & $\begin{array}{c}\text { Mou } \\
\text { ld } \\
(\mathrm{cfu} / \\
\left.\mathrm{m}^{3}\right)\end{array}$ & $\begin{array}{l}\text { Te } \\
\text { mp. } \\
\left({ }^{\circ} \mathrm{C}\right)\end{array}$ & $\begin{array}{c}\mathbf{R} \\
\mathbf{H} \\
( \\
\% \\
)\end{array}$ & $\begin{array}{l}\text { Wi } \\
\text { nd } \\
\text { (m/ } \\
\text { s) }\end{array}$ \\
\hline \multirow{3}{*}{$\begin{array}{c}\text { Service } \\
\text { Room }\end{array}$} & $\begin{array}{l}\text { Locat } \\
\text { ion } 1\end{array}$ & $900 *$ & 250 & 21.6 & $\begin{array}{c}57 \\
.1\end{array}$ & $\begin{array}{c}0.0 \\
0.1 \\
3\end{array}$ \\
\hline & $\begin{array}{l}\text { Locat } \\
\text { ion } 2\end{array}$ & $\begin{array}{c}1180 \\
*\end{array}$ & 160 & 24.2 & $\begin{array}{l}57 \\
.6\end{array}$ & $\begin{array}{c}0.0- \\
0.2 \\
8\end{array}$ \\
\hline & $\begin{array}{c}\text { Locat } \\
\text { ion } 3\end{array}$ & $890 *$ & 170 & 25.5 & $\begin{array}{c}60 \\
.2\end{array}$ & $\begin{array}{c}0.1 \\
0- \\
0.6 \\
0\end{array}$ \\
\hline
\end{tabular}

\begin{tabular}{|c|c|c|c|c|c|c|}
\hline & $\begin{array}{l}\text { Locat } \\
\text { ion } 4\end{array}$ & $710 *$ & 130 & 23.1 & $\begin{array}{l}70 \\
.7\end{array}$ & 0 \\
\hline & $\begin{array}{l}\text { Locat } \\
\text { ion } 5\end{array}$ & $\begin{array}{c}2250 \\
*\end{array}$ & 725 & 24.0 & $\begin{array}{r}49 \\
.5\end{array}$ & $\begin{array}{c}0.0- \\
0.0 \\
3\end{array}$ \\
\hline & $\begin{array}{l}\text { Locat } \\
\text { ion } 6\end{array}$ & $\begin{array}{c}1210 \\
*\end{array}$ & 630 & 29.1 & $\begin{array}{l}59 \\
.7\end{array}$ & $\begin{array}{c}0.1 \\
8- \\
0.3 \\
0\end{array}$ \\
\hline \multirow{6}{*}{$\begin{array}{c}\text { Room } \\
\text { Staff/ } \\
\text { Emplo } \\
\text { yees }\end{array}$} & $\begin{array}{l}\text { Locat } \\
\text { ion } 1\end{array}$ & 150 & 100 & 26.1 & $\begin{array}{c}55 \\
.2\end{array}$ & $\begin{array}{c}0.0- \\
0.0 \\
2\end{array}$ \\
\hline & $\begin{array}{l}\text { Locat } \\
\text { ion } 2\end{array}$ & $\begin{array}{c}1610 \\
*\end{array}$ & 50 & 23.8 & $\begin{array}{l}56 \\
.8\end{array}$ & $\begin{array}{c}0.0- \\
0.1 \\
2\end{array}$ \\
\hline & $\begin{array}{l}\text { Locat } \\
\text { ion } 3\end{array}$ & 590 & 140 & 25.3 & $\begin{array}{c}64 \\
.0\end{array}$ & $\begin{array}{c}0.2 \\
0 \text { to } \\
0.3 \\
0\end{array}$ \\
\hline & $\begin{array}{l}\text { Locat } \\
\text { ion } 4\end{array}$ & $\begin{array}{c}1300 \\
*\end{array}$ & 230 & 24.0 & $\begin{array}{l}62 \\
.5 \\
\end{array}$ & 0 \\
\hline & $\begin{array}{l}\text { Locat } \\
\text { ion } 5\end{array}$ & $\begin{array}{c}1400 \\
*\end{array}$ & $\begin{array}{c}1825 \\
*\end{array}$ & 25.3 & $\begin{array}{c}64 \\
.0\end{array}$ & $\begin{array}{c}0.0- \\
0.1 \\
2\end{array}$ \\
\hline & $\begin{array}{l}\text { Locat } \\
\text { ion } 6\end{array}$ & $\begin{array}{c}1630 \\
*\end{array}$ & 520 & 24.2 & $\begin{array}{l}75 \\
.4\end{array}$ & $\begin{array}{c}0.0 \\
3- \\
0.3 \\
1\end{array}$ \\
\hline \multirow{6}{*}{ Hall } & $\begin{array}{l}\text { Locat } \\
\text { ion } 1\end{array}$ & 325 & 175 & 21.6 & $\begin{array}{l}58 \\
.7\end{array}$ & $\begin{array}{c}0.0- \\
0.0 \\
6\end{array}$ \\
\hline & $\begin{array}{l}\text { Locat } \\
\text { ion } 2\end{array}$ & $\begin{array}{c}1190 \\
*\end{array}$ & 150 & 23.3 & $\begin{array}{l}58 \\
.3\end{array}$ & $\begin{array}{c}0.0- \\
0.1 \\
9\end{array}$ \\
\hline & $\begin{array}{l}\text { Locat } \\
\text { ion } 3 \\
\end{array}$ & - & - & - & - & - \\
\hline & $\begin{array}{l}\text { Locat } \\
\text { ion } 4\end{array}$ & - & - & - & - & - \\
\hline & $\begin{array}{l}\text { Locat } \\
\text { ion } 5\end{array}$ & - & - & - & - & - \\
\hline & $\begin{array}{l}\text { Locat } \\
\text { ion } 6\end{array}$ & $860 *$ & 250 & 24.5 & $\begin{array}{l}67 \\
.0\end{array}$ & $\begin{array}{c}0.0- \\
0.1 \\
7\end{array}$ \\
\hline $\begin{array}{c}\text { Descri } \\
\text { ption }\end{array}$ & \multicolumn{6}{|c|}{$*=$ Exceed Standard } \\
\hline \multicolumn{2}{|c|}{$\begin{array}{l}\text { Standard: } \\
\text { Permenaker RI } \\
\text { No. 5-year 2018 }\end{array}$} & $<700$ & $\stackrel{<}{1000}$ & - & - & - \\
\hline \multicolumn{2}{|c|}{$\begin{array}{l}\text { Permenkes No. } \\
48 \text { Year } 2016\end{array}$} & $<700$ & $\stackrel{<}{1000}$ & $\begin{array}{l}23- \\
26\end{array}$ & $\begin{array}{l}40 \\
- \\
60\end{array}$ & $\begin{array}{c}0.1 \\
5- \\
0.5\end{array}$ \\
\hline
\end{tabular}

It can be inferred from the table that the service room of all sample locations showing bacterial numbers that exceed the standard from The Ministry of Labor and Ministry of Health. As for the employee room, four out of six bank offices have high number of bacteria. While for the office hall, only two locations show high numbers of bacteria. Information on microbial concentrations (bacteria and fungi) is necessary to estimate health hazards as well as to create a standard of indoor air quality

Bioedukasi Vol. XVII. No. 2 October 2019 
control (Hayleeyesus and Melaku, 2014).

Air quality in a room is influenced by biological factors (known as Bioaerosols) and physical factors. Bioaerosols are various particles in the air with biological origins. Bioaerosols can consist of viruses, bacteria, fungi, algae, pollen plants, metabolites, endotoxin, mycotoxin, glucan, and fragments of organic matter (Moldoveanu, 2015). Sturm (2016) states bioaerosol can be harmful to human in a certain concentration. The presence of bioaerosols can be associated with human diseases, such as pneumonia, influenza, measles, asthma, allergies, and digestive disorders (Srikanth et al., 2008).

There are eight (8) main sources of indoor microbes that include pets, plants, plumbing systems, heating systems, ventilation, air conditioning, dust suspenders, and outside environments (Prusin and Marr, 2015). Ecological factors affect the development and dissemination of indoor microbes. Ecological factors affecting the presence of indoor microbes include temperature, humidity, lighting, room size, room cleanliness, and ventilation (Dedesko et al., 2015; Purnamasari et al., 2017).

The physical factors measurement result indicates that several sampling points have not fulfilled the minimummaximum standard of physical environmental conditions according to PERMENKES No. 48, the year of 2016, on the minimum requirements of air quality in an office room. The standard value for temperature ranges from $23-$ $26{ }^{\circ} \mathrm{c}$, while for humidity ranging between $40-60 \%$. Temperature and humidity have a high correlation to the existence of microorganisms. The low temperature will result in high humidity. High humidity can protect the microorganisms from the inactivation of
UV so that in the condition of high humidity levels of indoor six will also be higher (Niazi et al., 2015).

Sampling point that does not meet the minimum-maximum standard of physical condition for the workspace, including the service room at the location 4 with a humidity of $70.7 \%$, the service room in the location 6 that has a temperature of up to $29,1^{\circ} \mathrm{C}$, employee room in location 3 and 5 which has a humidity number reaches $64.0 \%$, employee room at location 4 has humidity $62.5 \%$, even room staff/employees at location 6 based on the data in Table 1 has a humidity rate up to $75.4 \%$.

The presence of bacteria is partly determined by temperature. A study conducted by Naddafi (2011) found that the temperature was positively correlated to the presence of bacteria. Bragoszewska (2017) displays that indoor bacteria may develop at temperatures ranging from $8^{\circ} \mathrm{C}$ to $27^{\circ} \mathrm{C}$. In line with Bragoszewska, Lal (2017) reveals that bacteria can live well at a temperature of $26^{\circ} \mathrm{C}$ to $30,8^{\circ} \mathrm{C}$. The temperature at each sampling point of 6 locations ranges from $21.6^{\circ} \mathrm{C}$ to $29,1^{\circ} \mathrm{C}$, making the points sampling from each location a good place for bacterial development.

Meanwhile, the value of relatively good humidity for bacterial growth is $>50 \%$ (Verdier et al., 2014). Abdullah and Hakim (2011) found the indoor humidity is directly related to the total number of germs in the air. Based on the data, three points sampling across locations have a humidity rate of $>50 \%$, which makes 3 point sampling on six research sites, a good place for bacterial growth.

As for fungal counts in this study was in line with Heikkinen (2005) and Bosshard (2011). Optimum growth of fungi obtained on temperature ranges 
from $25-30^{\circ} \mathrm{C}$, while moisture ranges from $60 \%-70 \%$. Based on data, the average temperature and moisture in 3 point sampling on each location show below optimum for fungal growth. However, there is one point sampling of the fifth location with a high number of fungi $(1825 \mathrm{cfu} / \mathrm{m} 3$ or above the standard). This condition is confirmed by the temperature and humidity of the room, which suitable for fungal growth.

The growth of microorganisms, both fungi and bacteria, in addition to being affected by temperature and humidity, is also affected by wind speed. Wind may increase the concentration of microbes in the air, but on the other hand, it can reduce the concentration of airborne microbes (Burrows et al., 2009). The wind can increase the microbial concentration at low speed, i.e., $<4 \mathrm{~m} / \mathrm{s}$, meanwhile if it is in high speed $>4 \mathrm{~m} / \mathrm{s}$, it reduces the concentration of microbes (Dueker et al., 2017). This condition is also a factor of the high concentration of microbes at 3 point sampling in 6 locations of the study. Table 1 shows that the wind speed was very low, it is even barely present. This condition results in non-air circulation in the space, so the microbes tend to settle.

Another factor that affects the microbial concentration in the air is human activities (Lax et al.,. 2014; Bhangar et al.,. 2016). human being can donate as many as 0.9 million biological aerosol particles per hour. An increase in the number of biological aerosol particles occurs from 5 to 69 million particles when humans walk or move their upper body. Conditions of sampling point with high human activities explain the high levels of microorganisms.

Indoor air quality has a direct correlation with air ventilation conditions. The data listed in Table 1 indicates that the bacteria at all sampling points has a very high number. This condition signifies less good air ventilation at each sampling point throughout the research site.

Canha (2015) suggests the level of indoor bacteria can be associated with insufficient occupancy and ventilation. A similar study by Leung (2015) found that air pollutants being transported in and out of residence depend on ventilation and infiltration. Opening windows frequently will be the right solution to this problem (Kalogerakis, 2005).

\section{CONCLUSION}

The existence of good microbial bacteria and fungi in this research still exceeds the maximum standard stipulated in the 2018 Permenaker RI No. 5 and the 2016 Permenkes RI No. 48. This condition is supported by physical environmental factors that include temperature, humidity, and wind speed at the research site that supports the growth of bacteria and fungi.

\section{REFERENCE}

Abdullah, M.T., and Hakim, B.A., 2011. Physical environment and room air germ in the public hospitalHaji Makassar, South Sulawesi. National Public Health journal. 5 (5).

Bhangar, S., Adams, R.I., Pasut, W., Huffman, J.A., Arens, E.A., Taylor, J.W., Bruns, T.D., and Nazaroff, W. W., 2016. Chamber bioaerosol Study: Human Emissions of Size Resolved Fluorescent Biological Aerosol Particles. Indoor Air. 26:193 $-206$

Bosshard, P. P., 2011. Incubation Of Fungal Cultures: How Long Is Long Enough? Mycoses. 54 (5). 539 - 545. 
Bragoszewska, E., Mainka, A., and Pastuszka, J.F., 2017. Concentration and Size Distribution of Culturable Bacteria in Ambient Air during Spring and Winter in Gliwice: A Typical Urban Area. Atmosphere. 8 (239): $1-13$.

Burrows, S. M., Elbert, W., Lawrence, M.G., and Poschl, U., 2009. Bacteria In The Global Atmosphere - Part 1: Review And Synthesis Of Literature Data For Different Ecosystems. Atmos. Chem. Phys. 9:9263-9280.

Canha, N., Mandin, C., Ramalho, O., Wyart, G., Ribéron, J., Dassonville, C., Hänninen, O., Almeida, S.M. \& Derbez, M. 2015. Assessment of Kolowa ventilation and indoor air pollutants in nursery and elementary schools in France. Indoor Air Journal (in press).

Cinninelli, A., and Martellini, T. 2017. Indoor Air Quality and Health. Int $J$ Environ Res Public Health. 14 (11): 1286

Dacarro, C. Grisoli, P., Del Frate, G., Villani, S., Grignani, E., and Cottica, D. Microorganisms And Dust Exposure In An Italian Grain Mill. $J$. Appl. Microbiol. 98:163 - 171.

De Giuli, V., Pos, O, D., and Carli, M. De. 2012. Indoor Environmental Quality And Pupil Perception In Italian Primary Schools. Building and Environment. 56:335 - 345.

Dedesko, S., Stephens, B., Gilbert, J.A., Siegel, J.A., 2015. Methods To Assess Human Occupancy And Occupant Activity In Hospital Patient Rooms. Build. Environ. 90: 136 145 .

Dueker, M.E., O'mullan, G.D., Martínez, J.M., Juhl, A. R. And Weathers, K.C. 2017. Onshore Wind Speed Modulates Microbial Aerosols Along An Urban Waterfront. Atmosphere. 8 (215): $1-14$.
Environmental Protection Agency (EPA). 2019. Introduction to Indoor Air Quality. https://www.epa.gov/indoorair-quality-iaq/introduction-indoorair-quality. [Retrieved 3 November 2019].

Gawrońska H and Bakera B. 2015. Phytoremediation Of Particulate Matter From Indoor Air By Chlorophytum comosum L. Plants. Air Quality, Atmosphere \& Health. 8 (3): $265-272$.

Gocgeldi, E., M.E. Berdan, M. Ucar, T. Turker, H. Istanbulluoglu, M. Gulec, and M. HASDE, 2011. Analysis of children's rooms in terms of microbiological air quality. Journal of Experimental and Integrative Medicine. 1 (1): 51-58.

Hayleeyesus, S.F., and Melaku, A., 2014. Microbiological Quality of Indoor Air in University Libraries. Asian Pacific Journal of Tropical Biomedicine. 4 (1): S312.

Heikkinen, M S.A., Hjelmroos - Koski, M.K., Häggblom, M.M., and Macher, J.M. 2005. Aerosols Handbook: Measurement, Dosimetry, and Health Effects. Boca Raton: CRC Press.

Jantunen M., de Oliveira Fernandes E., Carrer P., and Kephalopoulos S. 2011. Promoting Actions For Healthy Indoor Air (IAIAQ), European Commission Directorate-General for Health and Consumers, Luxembourg.

Kalogerakis, A., Paschali, D., Lekaditis, V., Pantidou, A., Eleftheriadis, K., and Lazaridis, M. 2015. Indoor Air Quality-Bioaerosol Measurements In Domestic And Office Premises. Journal of Aerosol Science. 36 (5): $751-761$.

Lal, H., Ghosh, B., Srivastava, A., Srivastava, A., 2017. Identification and Characterization of SizeSegregated Bioaerosols at Different 
Sites in Delhi. Aerosol and Air Quality Research. 17:1570 - 1581.

Lax S, Smith DP, Hampton-Marcell J. 2014. Longitudinal Analysis Of Microbial Interaction Between Humans And The Indoor Environment. Science. 345: 1048-1052.

Leung, D.Y.C., 2015. Outdoor - Indoor Air Pollution In Urban Environment: Challenges And Opportunity. Frontiers in Environmental Science. 2 (69): $1-7$.

Moldoveanu, A.M. 2015. Biological Contamination of Air in Indoor Spaces. Current Air Quality Issues. DOI: $10.5772 / 59727$.

Naddafi, K., Jabbari, H., Hoseini, M., Nabizadeh, R., Rahbar, M., \& Younesian, M. 2011. Investigation of indoor and outdoor air bacterial density in The Tehran subway system. Iranian Journal of Environmental Health Science \& Engineering. 8 (4), $383-388$.

Niazi, S., Hassanvand, M.S., Mahvi, A.H., Nabizadeh, R., Alimohammadi, M., Nabavi, S., Faridi, S., Dehghani, A., Hoseini, M. and Moradi-Joo, M. 2015. Assessment Of Bioaerosol Contamination (Bacteria and Fungi) In The Largest Urban Wastewater Treatment Plant In The Middle East. Environ. Sci. Pollut. Res. 22:16014 16021.

Paparang, F., 2016. Bank activities in gathering community funds. Legal Sciences Journals. III (9): 11 - 19.

Spring, P.N., Alves, C.A., Evtyugina, M.G., Nunes, T., Cerqueira, M., Franchi, M., Pio, C.A., Almeida, S.M., and Freitas, M.C. 2011. Indoor Air Quality In Elementary Schools Of Lisbon In Spring. Environmental Geochemistry and Health. 33 (5): 455 - 68.
Ministry of Health Regulation of the Republic of Indonesia number 48 the year 2016. Occupational Safety and Health Standards Office.

Ministerial regulation of the Republic of Indonesia number 5 the year 2018. Occupational Safety and health environment.

Prusin, A.J., and Marr, L.C., 2015. Sources Of Airborne Microorganisms In The Built Environment. 3:78.

Purnamasari, T., Suharno, and Selviana. 2017. Relation of physical environmental factor and standard room area with the quality of Air microbiology in the hospital treatment room of Bhayangkara Pontianak. Jumantik Journal of Students and health Research. 4 (1).

Srikanth, P., Sudharsanam, S., Steinberg, R., 2008. Bioaerosols In Indoor Environment: Composition, Health Effects Analysis. Ind. J. Med. Biol. 26: $302-312$.

Sturm, R., 2016. Bioaerosols In The bronchi Of Subjects With Different Ages Part 1 deposition Modeling. Ann. Transl. Med. 4 (11): 211 - 223.

Tamburrano, A, Sciaraffa, R., Borghini, A., Ricciardi, W., A De Martino, D D'alessandro, U Moscato. 2017. Sources of indoor air pollution and health effects in the Italian and European schools. European Journal of Public Health. 27 (3).

Verdier, T., Coutand, M., Bertron, A., and Roques, C. 2014. A Review Of Indoor Microbial Growth Across Building Materials And Sampling And Analysis Methods. Building and Environment. 80:136 - 149.

Zhang, J., and Smith, K.R. 2003. Indoor Air Pollution: A Global Health concern. 
British Medical Bulletin. 68:209 -

225. 